\title{
Effect of Various Nutrient Sources on Seedling Growth of Annona Muricata Linn
}

\author{
Dada C. A. \\ Department of Science Laboratory Technology (Biotechnology Option), Ekiti State University, Ado-Ekiti, Nigeria \\ Kayode J.* \\ Department of Plant Science and Biotechnology, Ekiti State University, Ado-Ekiti, Nigeria \\ Arowosegbe S. \\ Department of Plant Science and Biotechnology, Ekiti State University, Ado-Ekiti, Nigeria \\ Olaniyi T. A. \\ Department of Science Laboratory Technology (Biotechnology Option), Ekiti State University, Ado-Ekiti, Nigeria
}

\begin{abstract}
The impact of nutrient sources cannot be over emphasised in plant growth. Seedlings of Annona muricata were subjected to organic fertilizers, inorganic fertilizers and fertilizer-free treatmentsin this study. The organic fertilizers comprises of cow dung, poultry manure and water hyacinth, while NPK fertilizer was used as the inorganic manure and Top soil without fertilizer application was used as the control. The organic fertilizers were singly used and mixed at the rate of $100 \mathrm{~kg} / \mathrm{ha}$ and $200 \mathrm{~kg} / \mathrm{ha}$ while the inorganic fertilizer was used at the rate $100 \mathrm{~kg} / \mathrm{ha}$ and $200 \mathrm{~kg} / \mathrm{ha}$. The parameters taken were plant height, stem girth, leaf area and leaf production. Results obtained showed that poultry manure produced the tallest plants $(23.50 \mathrm{~cm})$ at 3 months after transplanting though this was not significantly different from those of cow dung manure $(23.00 \mathrm{~cm})$. NPK fertilizer produced the plant with highest leaf area $(32.75 \mathrm{~cm})$ and stem girth $(2.25 \mathrm{~cm})$ at 3 months after transplanting and was not significantly different from the organic fertilizers (Poultry manure 200g/ha, Cow dung 200g/ha, Water hyacinth 100g/ha and 200g/ha). NPK fertilizer also produced the highest number of leaves at the end of the three month assessment $(31.00 \mathrm{~cm})$. All the growth parameters observed showed that the control experiment gave the least performance. The results obtained tend to suggest that the use of NPK fertilizer should be recommended for growing Annona muricata and improvement of the soil nutrients level.
\end{abstract}

Keywords: Nutrient sources; Seedling growth; Annona muricata.

(9) (1) CC BY: Creative Commons Attribution License 4.0

\section{Introduction}

A nutrient is a substance used by an organism to survive, grow, and reproduce [1]. Plant nutrients consist of more than a dozen minerals absorbed through roots, plus carbon dioxide and oxygen absorbed or released through leaves. All organisms obtain all their nutrients from the surrounding environment [2]. The soil supplies nitrogen, phosphorus, potassium, calcium, magnesium, and sulphur [3]; these are often called the macronutrients. Also it supplies iron, manganese, boron, molybdenum, copper, zinc, chlorine, and cobalt, in small proportions, these are called micronutrients. Plants absorb carbon, hydrogen and oxygen from air in form of water and carbon dioxide [4, 5]. Thus, nutrients must be available not only in sufficient amounts but also in appropriate ratios [6].

Fertilizer recommendation for soils and crops is a dynamic process in view of the generation of the new knowledge, changes in soil nutrient status, changes in plants and planting patterns and associated management practices. Gathering the appropriate information on maintaining adequate soil nursery fertility into a single publication has been attempted many times in the past [7] and undoubtedly will be necessary again as conditions change and new information becomes available, Such specific information are very much important for producing better seedlings. Failure to manage nursery soil adequately can result in depletion of site quality [8] and a reduction of seedling growth [9]. Organic fertilizers are usually (recycled) plant- or animal-derived matter while inorganic fertilizers are sometimes called synthetic fertilizers since various chemical treatments are required for their manufacture [10].

Soursop (Annona muricata) is a slender, small, and cold-intolerant tree, generally reaching heights of 4-6 meters (13-20 feet); it flowers can bear fruit 3-5 years after planting. Leaves are glossy, dark green, and generally evergreen, with a distinctive odor [11]. The seeds and many parts of A. muricata are used in traditional medicine [12-14]. Badrie and Schauss [15] reported some of its uses in traditional Indian medicine as well as in Jamaica, Haiti, Brazil, the Peruvian Amazon for the treatment of kidney problems, fever, nervousness, ulcers and wounds, with antispasmodic, antidysenteric, and parasiticidal activity, for fever, its bark as tonic, roots as antispasmodic and parasiticidal, its flowers as bechic (relieving coughs), unripe fruit as antiscrobutic; and seeds as insecticidal, astringent, and as a fish-poison.

In addition to the health benefits, soursop along with other members of the Annonaceae family) also contains small amounts of neurotoxic alkaloids, such as annonacin, which appear to be linked to a typical parkinsonism and 
other neurological effects if consumed frequently or in large quantities $[16,17]$. It is necessary to promote the cultivation of this species, develop a more effective and faster means which might fulfill the requirements of growing Annona muricata. Fertilizers both organic and inorganic are to be promising in this respect as fertilizers enhances the growth of plants. Hence, the objective of this work was to assess the effect of various nutrient sources on seedling growth of Annona murricata.

\section{Materials and Methods}

\subsection{Study Area}

This study was conducted at the Greenhouse of the Department of Plant Science and Biotechnology, Ekiti State University, Ado-Ekiti, Ekiti State, Nigeria.

\subsection{Seed Source}

Fresh fruits of Annona muricata were collected from a parent plant in Saki, Oyo-State, Nigeria and were taken to the herbarium of the Department of Plant Science and Biotechnology, Ekiti State University, Ado-Ekiti, Nigeria for authentication.

\subsection{Collection and Preparation of Organic Fertilizers}

Cow dung and poultry manure were collected from Ekiti State University's Animal Farm, while water hyacinth was collected from Jetty River, Isashi community in Ikorodu, Lagos-State, Nigeria. All organic fertilizers were air dried for two weeks, after which they were grinded into powder according to AF [18]. The powders thus obtained from the three organic manures were sieved and chemically analysed at the Soil Laboratory in Faculty of Agriculture, Ekiti State University, Ado-Ekiti, Nigeria, to determine their physico-chemical properties before they were applied directly as nutrient sources.

\subsection{Collection of Inorganic Fertilizer}

NPK fertilizer was collected from a farm shop in Okesha Market, Ado-Ekiti, Nigeria. It was chemically analyzed at the soil laboratory, Faculty of Agriculture, Ekiti State University, Ado-Ekiti, Nigeria.

\subsection{Procedure of Application}

Fertilizer sources at $100 \mathrm{~kg} / \mathrm{ha}$ and $200 \mathrm{~kg} / \mathrm{ha}$ rates were singly used and also combined as organic fertilizers while NPK (15:15:15) was the only inorganic fertilizer used. The organic fertilizer was mixed with topsoil filled into black polythene bags containing $2 \pm 0.2 \mathrm{~kg}$ and left for a week for the manure to be mineralized. Uniformly growing seedlings of Annona muricata (3-month old) were transplanted into polythene bags containing topsoil. The organic fertilizers were applied a week before transplanting for the manure to be mineralized while the inorganic fertilizers were applied a week after transplanting. Seedlings without fertilizer application served as control. The seedlings were allowed to adjust to the fertilizer treatments for two weeks before data collection.

\subsection{Growth Assessment}

Assessment of growth variables such as plant height, leaf area, stem girth and leaf production were carried out on a weekly basis for three (3) months.

\subsection{Data Analysis}

The data collected were subjected to one way analysis of variance (ANOVA) and Duncan Multiple Range Test (DMRT) was used to separate the means at $5 \%$ level of probability. 
Journal of Biotechnology Research

Table-1. List of organic and inorganic fertilizer sources used in the experiments

\begin{tabular}{|c|c|}
\hline Treatment & Description \\
\hline \multicolumn{2}{|l|}{ Single organic source } \\
\hline T1-PM 100 & $100 \mathrm{~kg} / \mathrm{ha}$ of poultry manure \\
\hline T2-PM 200 & $200 \mathrm{~kg} / \mathrm{ha}$ of poultry manure \\
\hline T3-CD 100 & $100 \mathrm{~kg} / \mathrm{ha}$ of cow dung \\
\hline T4-CD 200 & $200 \mathrm{~kg} / \mathrm{ha}$ of cow dung \\
\hline T5-WH 100 & $100 \mathrm{~kg} / \mathrm{ha}$ of decomposed water hyacinth \\
\hline T6-WH 200 & $200 \mathrm{~kg} / \mathrm{ha}$ of decomposed water hyacinth \\
\hline \multicolumn{2}{|l|}{ Single inorganic source } \\
\hline T7-NPK 100 & $100 \mathrm{~kg} / \mathrm{ha}$ of $\mathrm{NPK}(15: 15: 15)$ \\
\hline T8-NPK 200 & $200 \mathrm{~kg} / \mathrm{ha}$ of $\mathrm{NPK}(15: 15: 15)$ \\
\hline \multicolumn{2}{|l|}{ Double organic source } \\
\hline T9- PM 100xCD 100 & Combination of $1: 1$ decomposed poultry manure and cow dung \\
\hline T10-PM 100xCD 200 & Combination of 1:2 decomposed poultry manure and cow dung \\
\hline T11-PM 200xCD 100 & Combination of $2: 1$ decomposed poultry manure and cow dung \\
\hline T12-PM 200xCD 200 & Combination of $2: 2$ decomposed poultry manure and cow dung \\
\hline T13-PM 100xWH 100 & $\begin{array}{l}\text { Combination of } 1: 1 \text { decomposed poultry manure and water } \\
\text { hyacinth }\end{array}$ \\
\hline T14-PM 100xWH 200 & $\begin{array}{l}\text { Combination of } 1: 2 \text { decomposed poultry manure and water } \\
\text { hyacinth }\end{array}$ \\
\hline T15-PM 200xWH 100 & $\begin{array}{l}\text { Combination of } 2: 1 \text { decomposed poultry manure and water } \\
\text { hyacinth }\end{array}$ \\
\hline T16-PM 200xWH 200 & $\begin{array}{l}\text { Combination of } 2: 2 \text { decomposed poultry manure and water } \\
\text { hyacinth }\end{array}$ \\
\hline T17-CD 100xWH 100 & Combination of 1:1 decomposed cow dung and water hyacinth \\
\hline T18-CD 100xWH 200 & Combination of 1:2 decomposed cow dung and water hyacinth \\
\hline T19-CD 200xWH 100 & Combination of 2:1 decomposed cow dung and water hyacinth \\
\hline T20-CD 200xWH 200 & Combination of 2:2 decomposed cow dung and water hyacinth \\
\hline T21-Top soil(control) & Top soil(control) \\
\hline
\end{tabular}

\section{Results}

\subsection{Chemical Analyses of Nutrients in the Organic Sources used in the Experiments}

Table 2 shows the results of the chemical analyses of nutrients in the organic sources. It was revealed that the nutrients and soil used were acidic. Cow dung has the highest organic carbon $(271 \mathrm{~g} / \mathrm{kg})$ and the highest value for total Nitrogen $(38.20 \mathrm{~g} / \mathrm{kg}$ ) and this was followed by poultry manure with organic carbon and total Nitrogen of $(223.75 \mathrm{~g} / \mathrm{kg})$ and $(25.25 \mathrm{~g} / \mathrm{kg})$ respectively. Water hyacinth recorded the least value for organic carbon and total nitrogen of $(96.90 \mathrm{~g} / \mathrm{kg})$ and $(10.65 \mathrm{~g} / \mathrm{kg})$ respectively. Only the topsoil has the following organic materials: Available phosphorus, sand, silt, clay and textural class of $18.53 \mathrm{mg} / \mathrm{kg}, 86.60 \%, 8.64 \%, 4.76 \%$ and loamy sand respectively.

\subsection{Effects of Different Nutrient Sources on Plant Height of Annona Muricata}

The effects of varying nutrient s0ources on plant height of Annona muricata is shown in Table 3 . The results revealed that there were significant differences $(\mathrm{p} \leq 0.05)$ in the effects of nutrient sources on seedling performance of Annona muricata. The highest plant height $(23.50 \mathrm{~cm})$ was recorded in seedlings treated with poultry manure applied at the rate of $200 \mathrm{~kg} / \mathrm{ha}$ at the end of three month assessment though was not significantly different from the seedlings treated with $100 \mathrm{~kg} / \mathrm{ha}$ and $100 \mathrm{~kg} / \mathrm{ha}$ of poultry manure $\mathrm{x}$ cow dung $(23.00 \mathrm{~cm})$ and the seedlings treated with $100 \mathrm{~kg} / \mathrm{ha}$ and $200 \mathrm{~kg} / \mathrm{ha}$ of poultry manure $\mathrm{x}$ cow dung $(23.25 \mathrm{~cm})$ the treatment that gave highest plant height at three month of assessment also gave the highest plant height $(10.70 \mathrm{~cm}$ and $15.00 \mathrm{~cm})$ at one and two months of assessment respectively. The least plant height at three month of assessment was recorded in seedlings without fertilizer (control) with the mean value of $16.50 \mathrm{~cm}$.

\subsection{Effects of Different Nutrients Sources on Leaf Area of Annona Muricata}

Table 4 shows the effects of varying nutrient sources on leaf area of Annona muricata. The results revealed that there were significant difference $(\mathrm{p} \leq 0.05)$ in the effects of nutrient sources on seedling performance. The seedlings treated with NPK applied at the rate of $200 \mathrm{~kg} / \mathrm{ha}$ produced the highest leaf area $(32.75 \mathrm{~cm})$ at the end of the three month assessment though was not significantly different from the seedling treated with $200 \mathrm{~kg} / \mathrm{ha}$ and $100 \mathrm{~kg} / \mathrm{ha}$ of Poultry manure $\mathrm{x}$ water hyacinth $(32.25 \mathrm{~cm})$, the seedlings treated with $100 \mathrm{~kg} / \mathrm{ha}$ and $100 \mathrm{~kg} / \mathrm{ha}$ of cow dung $\mathrm{x}$ water hyacinth $(31.50 \mathrm{~cm})$ and the seedlings treated with $200 \mathrm{~kg} / \mathrm{ha}$ and $200 \mathrm{~kg} / \mathrm{ha}$ of cow dung $\mathrm{x}$ water hyacinth $(31.50 \mathrm{~cm})$. The treatment that gave highest leaf area at three month of assessment also gave highest leaf area at one month of assessment $(13.50 \mathrm{~cm})$ and at two month of assessment $(28.00 \mathrm{~cm})$ respectively. The least leaf area at the end of the three month assessment was recorded in seedlings without fertiliser (control) with the mean value of $20.00 \mathrm{~cm}$. 


\subsection{Effects of Different Nutrient Sources on Plant Stem Girth of Annona Muricata}

The effects of different nutrient sources on stem girth of Annona muricata is shown in Table 5. The results revealed that there were significant difference $(\mathrm{p} \leq 0.05)$ in the effect of nutrient sources on seedlings performances of Annona muricata. The highest stem girth $(2.25 \mathrm{~cm})$ was recorded in seedling treated with NPK applied at $200 \mathrm{~kg} / \mathrm{ha}$ at the end of the three month assessment though was not significantly different from seedlings treated with $200 \mathrm{~kg} / \mathrm{ha}$ of poultry manure $(2.13 \mathrm{~cm}), 200 \mathrm{~kg} / \mathrm{ha}$ of cow dung $(2.10 \mathrm{~cm}), 100 \mathrm{~kg} / \mathrm{ha}$ and $200 \mathrm{~kg} / \mathrm{ha}$ of Water hyacinth $(2.20 \mathrm{~cm}$ and $2.20 \mathrm{~cm}$ respectively), $100 \mathrm{~kg} / \mathrm{ha}$ of NPK $(2.10 \mathrm{~cm}), 100 \mathrm{~kg} / \mathrm{ha}$ and $100 \mathrm{~kg} / \mathrm{ha}$ of poultry manure x cow dung $(2.10 \mathrm{~cm})$, $100 \mathrm{~kg} / \mathrm{ha}$ and $200 \mathrm{~kg} / \mathrm{ha}$ of poultry manure $\mathrm{x}$ cow dung $(2.10 \mathrm{~cm}), 200 \mathrm{~kg} / \mathrm{ha}$ and $200 \mathrm{~kg} / \mathrm{ha}$ of poultry manure $\mathrm{x}$ cow dung $(2.10 \mathrm{~cm}), 100 \mathrm{~kg} / \mathrm{ha}$ and $100 \mathrm{~kg} / \mathrm{ha}$ of poultry manure $\mathrm{x}$ water hyacinth $(2.20 \mathrm{~cm}), 100 \mathrm{~kg} / \mathrm{ha}$ and $200 \mathrm{~kg} / \mathrm{ha}$ of poultry manure $x$ water hyacinth $(2.16 \mathrm{~cm}), 200 \mathrm{~kg} / \mathrm{ha}$ and $100 \mathrm{~kg} / \mathrm{ha}$ of poultry manure $\mathrm{x}$ water hyacinth $(2.15 \mathrm{~cm})$, $200 \mathrm{~kg} / \mathrm{ha}$ and $200 \mathrm{~kg} / \mathrm{ha}$ of poultry manure $\mathrm{x}$ water hyacinth $(2.06 \mathrm{~cm}), 100 \mathrm{~kg} / \mathrm{ha}$ and $100 \mathrm{~kg} / \mathrm{ha}$ of cow dung x water hyacinth $(2.10 \mathrm{~cm}), 200 \mathrm{~kg} / \mathrm{ha}$ and $100 \mathrm{~kg} / \mathrm{ha}$ of cow dung $\mathrm{x}$ water hyacinth $(2.15 \mathrm{~cm})$ and $200 \mathrm{~kg} / \mathrm{ha}$ and $200 \mathrm{~kg} / \mathrm{ha}$ of cow dung $\mathrm{x}$ water hyacinth $(2.10 \mathrm{~cm})$. The treatment that gave the highest stem girth at the end of the three month assessment also gave the highest stem girth at 2 month of assessment $(2.05 \mathrm{~cm})$, seedling treated with water hyacinth applied at the rate of $200 \mathrm{~kg} /$ ha produced the highest stem girth $(1.58 \mathrm{~cm})$ at one month of assessment. The least stem girth at the end of the three month assessment was recorded in seedlings without fertiliser (control) with the mean value of $1.85 \mathrm{~cm}$.

\subsection{Effects of Different Nutrient Sources on Leaf Production of Annona Muricata}

The effects of varying nutrient sources of leaf production of Annona muricata is shown in Table 6. The results revealed that there were significant difference $(\mathrm{p} \leq 0.05)$ in the effect of nutrient source on seedlings performance of Annona muricata. The seedling that produced the highest number of leaves after the three month assessment was seedling treated with NPK at $200 \mathrm{~kg} / \mathrm{ha}(31.00 \mathrm{~cm})$ and was significantly different from the other treatments. The treatment that gave the highest leaf production at three month of assessment also gave the highest leaf production $(12.00 \mathrm{~cm}$ and $8.00 \mathrm{~cm})$ at one month and two month of assessment respectively. The least leaf production at the end of the three month of assessment was recorded in seedlings without fertiliser (control) with the mean value of $15.50 \mathrm{~cm}$.

\section{Discussion}

Results obtained from the study revealed that cow dung and poultry manure highly favoured the plant height of Annona muricata. This might be as a result of the highest release of nitrogen and phosphorus from the organic fertilizer. Yinda and Adeoye [19]; Adediran, et al. [20] had earlier reported that organic fertilizer produce better yields of crops that keep longer and more nutritious than inorganic fertilizers. Wu, et al. [21] noted that biofertilizers such as organic manures has been identified as an alternative to chemical fertilizer to increase soil productivity and crop production in suitable farming. The increase in the plant height might also be due to the improved soil fertility and soil water holding capacity. This corroborated the earlier assertions of Fallah-Hoesini, et al. [22] who noted that increase in plant height can be improved by improved soil fertility.

The results from this study shows that the highest leaf area was observed in seedlings treated with NPK fertilizer though was similar to that of poultry manure $\mathrm{x}$ water hyacinth and cow dung $\mathrm{x}$ water hyacinth. This observation is supported by the work of Omotoso and Shittu [23] who noted that NPK fertilizer significantly increase growth parameters (plant height, leaf area, root length and number of leaves) in okra (Abelmoschus esculentus (L.) Moench).

This study revealed that NPK fertilizer produced the highest stem girth in Annona muricata. Reason for this might be due to fact that NPK fertilizer is a mixture of nitrogen, phosphorus and potassium which are essential for plant growth. This observation is supported by the work of Aliyu and Olanrewaju [24] who noted that the beneficial effects of nitrogen, phosphorus and potassium could be seen in the increase of stem girth of Capsicum annum and thus interpreted as accumulative growth.

The highest number of leaves experienced with the use of NPK fertilizer in this study might be as a result of the presence of nitrogen in NPK fertilizer which led to the formation of more buds and increase in the number of leaves for photosynthesis and conserve energy. This corroborated the study of Zhang, et al. [25] who noted that nitrogen generally stimulates vegetative growth. Olaniyi, et al. [26]; Olaniyi and Ojetayo [27] also reported that plants increased in growth with increasing rate of nitrogen fertilizer and vegetative cropping system requires a greater degree of management. They noted that nitrogen increases the cell size and cellular number resulting from cell division and expansion that leads to increased stem girth, number of leaves and other vegetative parts of the plants.

\section{Conclusion and Recommendation}

The study revealed that NPK (inorganic fertilizer) improve the growth performance of Annona muricata seedlings. Though cow dung and poultry manure (organic fertilizers) supported the growth of this species to an extent and are cheaper to get, inorganic fertilizer released more nutrients to the soil which eventually led to the better performance of this species. Deciding which fertilizer to be used however depends on farmer's choice after considering the cost and other factors. 


\section{References}

[1] Audrey, H. E., 1994. Foods and nutrition encyclopaedia. Boca Raton, Florida, USA: CRC Press.

[2] Whitney, E. and Sharon, R., 2005. Understanding nutrition. 10th ed. California: Thomson-Wadsworth, Places Belmont. p. 6.

[3] Allen, V., Barker, D., and Pilbeam, J., 2007. Handbook of plant nutrition. Boca Raton, FL.: CRC Press. p. 613.

[4] Jones, J. and Benton, J., 1998. Plant nutrition manual. Florida, USA: CRC, Press, Boca Raton. p. 34.

[5] WSJ, 2010. "New linkbin chain of life." Wall Street Journal,

[6] Norman, P., Huner, A., and William, H., 2008. Introduction to plants physiology. 4th ed. New Jersey, USA.: John Wiley and son. Inc.

[7] Anderson, H. W. and Gessel, S. P., 1996. "Effects of nursery fertilization on out planted Douglas-fir." J. For., vol. 64, pp. 109-112.

[8] Anonymous, 1997. Fertilizer recommended guide. BARC, Dhaka, p. 196.

[9] Austey, C., 1971. "Survival and growth of 1/10 radiata pine seedlings." J. For., vol. 16, pp. 77-81.

[10] Jones, J. and Benton, J., 2012. Inorganic chemicals fertilizers and their properties, in plant nutrition and soil fertility manual. Boca Raton, Florida, USA: CRC, Press.

[11] Morton, J., 1987. "Soursop, Fruits of warm climates. Julia f-morton, miami, fl." pp. 75-80. Available: https://hort.purdue.edu/newcrop/morton/soursop.html

[12] Hanelt, P., Buttner, R., and Mansfeld, R., 2001. Mansfeld's encyclopedia of agricultural and horticultural crops (except ornamentals). Springer, Berlin, Germany.

[13] Orwa, C., Mutua, A., Kindt, R., Jamnadass, R., and Anthony, S., 2009. "Agroforestry database: a tree reference and selection guide". Version 4.0." Available: http://www.worldagroforestry.org/resources/database/agroforestree

[14] USDA-ARS, 2014. Germplasm resources information network (GRIN). National Germplasm Resources Laboratory, Beltsville, Maryland, USA.

[15] Badrie, N. and Schauss, A. G., 2010. Soursop (annona muricata l.): Composition, nutritional value, medicinal uses and toxicology”. Pp. 621-643. In: Watson r.R. And preedy, v. R. (eds). Bioactive foods in promoting health. Academic Press: Amsterdam, Netherlands.

[16] Champy, P., Melot, A., Guerineau, V., Gleye, C., Fall, D., Hoglinger, G., and Hocqemiller, R., 2005. "Quantification of acetogenins in Annona muricata linked to a typical parkinsonism in Guadeloupe." Moved. Disord., vol. 20, pp. 1629-1633.

[17] Caparros-Lefebvre, D. and Elbaz, A., 1999. "Possible relation of atypical parkinsonism in the French West Indies with consumption of tropical plants: a case-control study." Lancet, vol. 354, pp. 281-285.

[18] AF, 2005. Preparation and use of compost. Wageningen, Netherlands: Agrodok-Series Number 8, Agromisa Foundation.

[19] Yinda, G. S. and Adeoye, G. O., 1994. A comparative study of two compositing methods. Proceedings of 3rd African Soil Science Society Conference, Ibadan, Nigeria.

[20] Adediran, J. A., Taiwo, L. B., Akande, M. O., and Sobulo, R. A., 1999. "Comparative effects of organic based fertilizer and mineral fertilizer on the dry matter yield of maize." Biose Research Communication,

[21] Wu, S. C., Cao, Z. H., Li, Z. G., Chevng, K. C., and Wong, M. H., 2005. "Effect of bio-fertilizer containing- fertilizer, $\mathrm{P}$ and $\mathrm{K}$ solubilizers and Am fungi on maize growth: A greenhouse trials." Society Direct-Geoderma, vol. 125, pp. 155-166.

[22] Fallah-Hoesini, H., Fakhrzadeh, H., Larijani, B., and Shikhsamani, A., 2006. "A review of anti-diabetic medicinal plant used in traditional medicine." Journal of Medicinal Plants, vol. 5, pp. 1-8.

[23] Omotoso, S. O. and Shittu, O. S., 2007. "Effect of NPK fertilizer rates and method of application on growth and yield of okra (Abelmoschus esculentus (L.) Moench) at Ado-Ekiti, Southwestern Nigeria." International Journal of Agricultural Research, vol. 2, pp. 614-619.

[24] Aliyu, D. and Olanrewaju, J. D., 1996. "Response of pepper to fertilizers, nutrient concentration and uptake as affected by nitrogen and phosphorus level." In Proc. 14th Horton Conference, Ago-Iwoye.

[25] Zhang, J., Blackmer, A. M., and Kyveryga, M., 2010. "Fertilizer bands and dual effects of Nitrogen on young corn plants." Better Crops, vol. 94, pp. 17-19.

[26] Olaniyi, J. O., Adelasoye, K. A., and Jegede, C. O., 2008. "Influence of Nitrogen fertilizer on the growth, yield and quality of grain amaranth varieties." World Journal of Agriculture Sciences, vol. 4, pp. 506-513. 
Journal of Biotechnology Research

Table-2. Physico-chemical properties of nutrient sources and soils used for the study

\begin{tabular}{l|l|l|l|l}
\hline Samples & Cow dung & Poultry manure & Water hyancith & Top soil \\
\hline $\mathrm{Ph}$ & 7.41 & 7.23 & 6.97 & 6.61 \\
\hline $\mathrm{O} . \mathrm{C}(\mathrm{g} / \mathrm{kg})$ & 271 & 223.75 & 96.90 & 20.30 \\
\hline $\mathrm{Ca}(\mathrm{cMol} / \mathrm{kg})$ & 6.53 & 38.56 & 48.17 & 5.75 \\
\hline $\mathrm{Mg}(\mathrm{cMol} / \mathrm{kg})$ & 2.87 & 18.31 & 6.79 & 1.24 \\
\hline $\mathrm{K}(\mathrm{cMol} / \mathrm{kg})$ & 10.33 & 42.23 & 3.92 & 0.28 \\
\hline Total P $(\%)$ & 0.17 & 0.74 & 0.12 & - \\
\hline $\mathrm{N}(\mathrm{g} / \mathrm{kg})$ & 38.20 & 25.25 & 10.65 & 3.75 \\
\hline AvailableP $(\mathrm{mg} / \mathrm{kg})$ & - & - & - & 18.53 \\
\hline Sand $(\%)$ & - & - & - & 86.60 \\
\hline Silt $(\%)$ & - & - & - & 8.64 \\
\hline Clay $(\%)$ & - & - & - & 4.76 \\
\hline Textural class & - & - & - & Loamy sand \\
\hline
\end{tabular}

Table-3. Effects of different nutrients sources on plant height of Annona muricata

\begin{tabular}{|c|c|c|c|c|}
\hline Treatment & Initial & \multicolumn{3}{|c|}{ Months after transplant } \\
\hline PM 100 & 8.00 & $9.73^{\mathrm{BbC}}$ & $14.00^{\text {s0 }}$ & $20.63^{\text {bed }}$ \\
\hline PM 200 & 8.30 & $10.70^{\circ}$ & $15.00^{2}$ & $23.50^{\circ}$ \\
\hline CD 100 & 8.00 & $9.75^{\text {abe }}$ & $13.89^{\text {sb }}$ & $21.25^{\mathrm{bc}}$ \\
\hline CD 200 & 8.00 & $9.50^{\text {bod }}$ & $14.00^{\text {bed }}$ & $22.75^{\mathrm{bc}}$ \\
\hline WH 100 & 8.00 & $8.50^{d}$ & $11.25^{\mathrm{f}}$ & $17.00^{\mathrm{Hi}}$ \\
\hline WH 200 & 8.00 & $8.50^{d}$ & $12.58^{\text {cde }}$ & $20.00^{d 0}$ \\
\hline NPK 100 & 8,00 & $9.63^{\text {be }}$ & $12.24^{\text {def }}$ & $19.38^{\text {ef }}$ \\
\hline NPK 200 & 8.30 & $9.38^{\text {cd }}$ & $12.50^{\text {cde }}$ & $21.00^{\text {d }}$ \\
\hline PM100XCD 100 & 8.10 & $9.77 \%$ & $13.25^{\text {bed }}$ & $23.00^{*}$ \\
\hline PM100XCD200 & 8.00 & $10.75^{*}$ & $14.05^{\text {ab }}$ & $23.25^{2}$ \\
\hline PM200XCD100 & 8.20 & $9.89^{\text {nbc }}$ & $13.25^{\text {bed }}$ & $21.00^{\text {ed }}$ \\
\hline PM200XCD200 & 8.00 & $9.50^{\text {bed }}$ & $13.75^{\mathrm{bb}}$ & $21.50 \mathrm{~b}$ \\
\hline PM100XWH 100 & 8.00 & $9.30^{\text {cd }}$ & $13.75^{a b c}$ & $20.75^{\text {bod }}$ \\
\hline PM100XWH200 & 8.00 & $9.26^{\text {वd }}$ & $11.00^{\text {feh }}$ & $17.20^{\mathrm{si}}$ \\
\hline PM200XWH 100 & 8.00 & $9.50^{\mathrm{bcd}}$ & $12.00^{\text {def }}$ & $21.57^{\circ}$ \\
\hline PM200XWH200 & 8.20 & $10.50^{\mathrm{mb}}$ & $13.30^{\text {bed }}$ & $21.50^{b}$ \\
\hline CD100XWH 100 & 8.00 & $10.50^{\circ b}$ & $12.50^{\text {odo }}$ & $18.00 \mathrm{gh}$ \\
\hline CD100XWH200 & 8.30 & $9.25^{\text {cd }}$ & $12.75^{\text {bedu }}$ & $20.25^{\text {cd. }}$ \\
\hline CD200XWH 100 & 8.00 & $8.50^{d}$ & $10.38^{\mathrm{th}}$ & $17.50^{\mathrm{hi}}$ \\
\hline $\mathrm{CD} 200 \times W H 200$ & 8.10 & $8.50^{d}$ & $11.50^{-68}$ & $18.25 \%$ \\
\hline CONTROL & 8.00 & $8.50^{d}$ & $10.00^{\mathrm{h}}$ & $16.50^{1}$ \\
\hline
\end{tabular}

Means, followed by the same alphabet in each column for each parameter, were not significantly different from each other (DMRT at $5 \%$ level of probability)

Table-4. Effects of different nutrient sources on leaf area of Annona muricata

\begin{tabular}{|c|c|c|c|c|}
\hline Treaments & Iinitials & $\begin{array}{l}\text { Month } \\
\text { One }\end{array}$ & $\begin{array}{l}\text { Transplant } \\
\text { Two }\end{array}$ & Three \\
\hline PM 100 & 6.50 & $6.57^{\mathrm{d}}$ & $14.75^{\mathrm{jk}}$ & $26.38^{\mathrm{fg}}$ \\
\hline PM 200 & 6.50 & $7.21^{\mathrm{d}}$ & $15.75^{\mathrm{ij}}$ & $20.25^{j}$ \\
\hline CD 100 & 6.00 & $6.75^{\mathrm{d}}$ & $13.25^{\mathrm{Im}}$ & $29.00^{\mathrm{cd}}$ \\
\hline CD 200 & 6.00 & $7.31^{d}$ & $14.00^{\mathrm{KI}}$ & $25.00^{\text {gh }}$ \\
\hline WH 100 & 6.00 & $10.50^{b}$ & $22.75^{\mathrm{e}}$ & $30.00^{\mathrm{bc}}$ \\
\hline WH 200 & 7.00 & $8.75^{\mathrm{c}}$ & $23.75^{\text {cde }}$ & $25.00^{\text {gh }}$ \\
\hline NPK 100 & 6.50 & $10.63^{b}$ & $26.00^{b}$ & $28.93^{\mathrm{cd}}$ \\
\hline NPK 200 & 6.75 & $13.50^{\mathrm{a}}$ & $28.00^{\mathrm{a}}$ & $32.75^{\mathrm{a}}$ \\
\hline PM 100XCD 100 & 6.00 & $8.75^{c}$ & $15.13^{\mathrm{jk}}$ & $20.50^{j}$ \\
\hline PM 100XCD 200 & 6.50 & $9.50^{\mathrm{bc}}$ & $19.00^{\mathrm{tg}}$ & $26.50^{\mathrm{fg}}$ \\
\hline PM 200XCD 100 & 6.00 & $8.63^{c}$ & $20.00^{f}$ & $26.63^{f}$ \\
\hline PM 200XCD 200 & 6.50 & $8.50^{c}$ & $18.00^{\text {gh }}$ & $25.20^{\text {gh }}$ \\
\hline PM100XWH 100 & 6.20 & $8.50^{c}$ & $24.50^{c}$ & $30.50^{\mathrm{bc}}$ \\
\hline PM100XWH 200 & 6.25 & $8.43^{\mathrm{c}}$ & $17.50^{\mathrm{h}}$ & $30.00^{b c}$ \\
\hline PM200XWH 100 & 6.35 & $8.50^{c}$ & $23.75^{\text {cde }}$ & $32.25^{\mathrm{a}}$ \\
\hline PM200XWH 200 & 6.50 & $8.38^{c}$ & $16.00^{1}$ & $29.50^{c}$ \\
\hline CD 100 XWH 100 & 6.45 & $10.39^{b}$ & $23.25^{\mathrm{de}}$ & $31.50^{\mathrm{ab}}$ \\
\hline CD 100XWH 200 & 6.50 & $9.50^{\mathrm{bc}}$ & $19.50^{f}$ & $28.00^{\mathrm{de}}$ \\
\hline CD 200XWH 100 & 6.50 & $13.50^{\mathrm{a}}$ & $24.25^{\mathrm{c}}$ & $22.70^{1}$ \\
\hline CD 200XWH 200 & 6.15 & $13.13^{\mathrm{a}}$ & $19.25^{\mathrm{f}}$ & $31.50^{\mathrm{ab}}$ \\
\hline CONTROL & 6.00 & $7.00^{\mathrm{d}}$ & $12.75^{\mathrm{m}}$ & $20.00^{j}$ \\
\hline
\end{tabular}

Means, followed by the same alphabet in each column for each parameter, are not significantly different from each other (DMRT at $5 \%$ level of probability) 
Journal of Biotechnology Research

Table-5. Effects of different nutrient sources on plant stem girth of Annona muricata

\begin{tabular}{|c|c|c|c|c|}
\hline Treatment & Initial & $\begin{array}{l}\text { Months } \\
\text { One }\end{array}$ & $\begin{array}{l}\text { ansplanting } \\
\text { Two }\end{array}$ & Three \\
\hline PM 100 & 1.00 & $1.18^{\mathrm{cd}}$ & $1.55^{\text {cde }}$ & $2.05^{\mathrm{bc}}$ \\
\hline PM 200 & 1.10 & $1.13^{\mathrm{cd}}$ & $1.59^{\text {bcde }}$ & $2.13^{\mathrm{abc}}$ \\
\hline CD 100 & 1.10 & $1.23^{\mathrm{bcd}}$ & $1.50^{\text {cde }}$ & $2.05^{\mathrm{bc}}$ \\
\hline CD 200 & 1.00 & $1.20^{\mathrm{bcd}}$ & $1.45^{\mathrm{de}}$ & $2.10^{\mathrm{abc}}$ \\
\hline WH 100 & 1.05 & $1.50^{\mathrm{ab}}$ & $2.00^{\mathrm{ab}}$ & $2.20^{\mathrm{ab}}$ \\
\hline WH 200 & 1.15 & $1.58^{\mathrm{a}}$ & $1.70^{\text {abcde }}$ & $2.20^{\mathrm{ab}}$ \\
\hline NPK 100 & 1.13 & $1.50^{\mathrm{ab}}$ & $1.85^{\mathrm{abc}}$ & $2.10^{a b c}$ \\
\hline NPK 200 & 1.20 & $1.50^{\mathrm{ab}}$ & $2.05^{\mathrm{a}}$ & $2.25^{\mathrm{a}}$ \\
\hline PM100 X CD100 & 1.00 & $1.13^{\mathrm{cd}}$ & $1.40^{\mathrm{de}}$ & $2.10^{\mathrm{abc}}$ \\
\hline PM100 X CD 200 & 1.08 & $1.43^{\mathrm{abc}}$ & $1.65^{\mathrm{abcde}}$ & $2.10^{\mathrm{abc}}$ \\
\hline PM200 X CD 100 & 1.03 & $1.38^{\mathrm{cd}}$ & $1.55^{\mathrm{cde}}$ & $2.00^{\mathrm{cd}}$ \\
\hline PM200 X CD 200 & 1.15 & $1.56^{\mathrm{ab}}$ & $1.80^{\mathrm{abcd}}$ & $2.10^{\mathrm{abc}}$ \\
\hline PM100 XWH 100 & 1.00 & $1.38^{\mathrm{abcd}}$ & $1.60^{\text {bcde }}$ & $2.20^{\mathrm{ab}}$ \\
\hline PM100 XWH 200 & 1.08 & $1.36^{\mathrm{abcd}}$ & $1.50^{\text {cde }}$ & $2.16^{\mathrm{abc}}$ \\
\hline PM200 XWH 100 & 1.15 & $1.35^{\mathrm{abcf}}$ & $1.55^{\mathrm{cde}}$ & $2.15^{\mathrm{abc}}$ \\
\hline PM200 XWH 200 & 1.00 & $1.38^{\mathrm{abcd}}$ & $1.56^{\text {cde }}$ & $2.06^{\mathrm{bc}}$ \\
\hline CD100 X WH100 & 1.05 & $1.45^{\mathrm{abc}}$ & $1.55^{\mathrm{cde}}$ & $2.10^{\mathrm{abc}}$ \\
\hline CD100 X WH200 & 1.00 & $1.40^{\mathrm{abc}}$ & $1.50^{\text {cde }}$ & $2.00^{\mathrm{cd}}$ \\
\hline CD200 X WH100 & 1.00 & $1.40^{\mathrm{abc}}$ & $1.60^{\text {bcde }}$ & $2.15^{\mathrm{abc}}$ \\
\hline CD200 X WH200 & 1.15 & $1.40^{\mathrm{abc}}$ & $1.55^{\mathrm{cde}}$ & $2.10^{\mathrm{abc}}$ \\
\hline CONTROL & 1.10 & $1.20^{\mathrm{bcd}}$ & $1.35^{\mathrm{ef}}$ & $1.85^{\mathrm{d}}$ \\
\hline
\end{tabular}

Means, followed by the same alphabet in each column for each parameter, are not significantly different from each other (DMRT at 5\% level of probability)

Table-6. Effects of different nutrients sources on leaf production of Annona muricata

\begin{tabular}{|c|c|c|c|c|}
\hline \multirow[t]{2}{*}{ Treatments } & \multirow[t]{2}{*}{ Initial } & \multicolumn{3}{|c|}{ Months after transplanting } \\
\hline & & One & Two & Three \\
\hline PM 100 & 5.50 & $8.00^{\mathrm{g}}$ & $12.50^{\mathrm{f}}$ & $20.00^{f}$ \\
\hline PM 200 & 6.00 & $8.50^{\mathrm{fg}}$ & $14.00^{\text {def }}$ & $22.75^{\mathrm{de}}$ \\
\hline CD 100 & 6.00 & $9.00^{\mathrm{efg}}$ & $13.50^{\mathrm{ef}}$ & $20.00^{\mathrm{f}}$ \\
\hline CD 200 & 5.50 & $7.50^{\mathrm{g}}$ & $13.00^{\mathrm{ef}}$ & $22.00^{\mathrm{e}}$ \\
\hline WH 100 & 5.50 & $11.50^{\mathrm{ab}}$ & $14.00^{\mathrm{def}}$ & $23.00^{\text {cde }}$ \\
\hline WH 200 & 6.00 & $10.50^{\text {bcd }}$ & $14.50^{\text {bcde }}$ & $23.50^{\text {cde }}$ \\
\hline NPK 100 & 5.50 & $9.50^{\text {def }}$ & $14.00^{\mathrm{def}}$ & $27.00^{\mathrm{b}}$ \\
\hline NPK 200 & 5.50 & $12.00^{\mathrm{a}}$ & $18.00^{\mathrm{a}}$ & $31.00^{\mathrm{a}}$ \\
\hline PM 100XCD100 & 5.50 & $8.75^{\mathrm{efg}}$ & $15.00^{\mathrm{bcd}}$ & $22.75^{\mathrm{de}}$ \\
\hline PM100XCD200 & 6.00 & $8.75^{\mathrm{efg}}$ & $16.00^{b}$ & $23.15^{\text {cde }}$ \\
\hline PM 200XCD100 & 6.50 & $10.75^{\mathrm{abcd}}$ & $15.75^{\mathrm{bc}}$ & $24.50^{c}$ \\
\hline PM 200XCD 200 & 6.50 & $10.50^{\mathrm{bcd}}$ & $14.50^{\text {bcde }}$ & $20.00^{f}$ \\
\hline PM100XWH 100 & 6.25 & $9.75^{\text {cdef }}$ & $14.25^{\text {cde }}$ & $24.25^{\mathrm{cd}}$ \\
\hline PM100XWH 200 & 6.00 & $10.00^{\mathrm{cd}}$ & $15.00^{\mathrm{bcd}}$ & $22.00^{\mathrm{e}}$ \\
\hline PM200XWH 100 & 6.50 & $10.50^{\text {bcd }}$ & $14.75^{\mathrm{bcd}}$ & $20.00^{f}$ \\
\hline PM200XWH 200 & 6.00 & $11.00^{\mathrm{abc}}$ & $15.00^{\mathrm{bcd}}$ & $20.00^{f}$ \\
\hline CD 100XWH 100 & 6.50 & $9.00^{\mathrm{efg}}$ & $12.50^{f}$ & $18.50^{\mathrm{fg}}$ \\
\hline CD 100XWH 200 & 6.00 & $9.50^{\mathrm{def}}$ & $14.00^{\mathrm{def}}$ & $17.50^{\text {gh }}$ \\
\hline CD 200XWH 100 & 6.00 & $8.00^{g}$ & $14.50^{\text {bcde }}$ & $17.50^{\text {gh }}$ \\
\hline CD 200XWH 200 & 6.50 & $12.00^{\mathrm{a}}$ & $15.00^{\mathrm{bcd}}$ & $19.50^{f}$ \\
\hline CONTROL & 6.50 & $10.00^{\mathrm{cd}}$ & $10.50^{g}$ & $15.50^{1}$ \\
\hline
\end{tabular}

Means, followed by the same alphabet in each column for each parameter, are not significantly different from each other (DMRT at $5 \%$ level of probability) 